\title{
海绵城市理论及其在风景园林规划中的应用
}

\author{
潘颖 \\ 沈阳市园林规划设计院 \\ DOI:10.32629/as.v3i1.1766
}

[摘 要] 近年来, 生态学获得了快速发展, 传统意义上的人与自然的关系逐渐被瓦解, 关于新型人与自然关系的理念和方法层出不穷。其中, 关于 “海绵城市” 这一新理念得到了人们的广泛关注。通过 “渗、滞、蓄、净、用、排”等措施的综合应用, 能够最大限度缓解城市水生态问题。 因此,海绵城市建设不仅仅是一个追求建设目标的开发工程项目, 而是综合了城市水生态修复、城市水环境改善、城市水安全保障等的生态工程, 其建设是对新型城市发展理念的实践,有效推动了城市建设方式的转型。

[关键词]海绵城市; 风景园林; 规划设计；应用

海绵城市建设是生态设计研究的一大突破, 是城市发展理念和建设方 式的转型, 它通过利用生态措施和工程措施相结合、地上和地下相结合、 人工和自然相结合, 解决了城市内涝、水体黑臭等问题, 起到调节微气候、 改善水生态的作用。本文通过对海绵城市相关建设的分析, 借以提醒在园 林规划中应秉承节水优先、系统整治的原则, 着力建设集自然渗透、自然 积存、自然净化于一体的 “海绵城市”。

\section{1 海绵城市的设计理念}

建设海绵城市, 首先要扭转观念。传统城市建设模式, 处处是硬化路 面。每逢大雨, 主要依靠管渠、原站等 “灰色” 设施来排水, 以 “快速排除” 和 “末端集中” 控制为主要规划设计理念, 往往造成逢雨必涝, 旱涝急转。 根据《海绵城市建设技术指南》, 城市建设将强调优先利用植草沟、渗水 砖、雨水花园、下沉式绿地等 “绿色” 措施来组织排水, 以 “慢排缓释” 和 “源头分散” 控制为主要规划设计理念, 既避免了洪涝, 又有效的收集了 雨水。

建设海绵城市, 即构建低影响开发雨水系统, 主要是指通过 “渗、滞、 蓄、净、用、排” 等多种技术途径, 实现城市良性水文循环, 提高对径流雨 水的渗透、调蓄、净化、利用和排放能力, 维持或恢复城市的海绵功能。

\section{2 海绵城市理论对风景园林规划设计的积极意义}

“夏季到城里来看海” 是不少城市中网友苦中作乐的自嘲, 也是对城市 园林景观陈旧设计思想与手段吐槽, 更是对开展生态园林规划、实践海绵城 市建设的迫切希望。海绵作为一种早已为大众熟视无睹的寻常物普遍应用 于各行各业, 其对水的高渗透性、强吸附性早已受到使用者的充分认识与高 度评价。海绵城市理论正是对这种其貌不扬但朴实耐用属性的跨界延伸。

\section{3 海绵城市理论应用于风景园林规划设计}

不仅有助于积极汇集自然降水使之有机会实现循环使用, 而且有利于 逐步减少城市地表径流与积水造成的负面影响。更为重要的是, 海绵城市 理论的应用能够从根本上扭转长期延续的落后设计理念, 帮助风景园林规 划顺应时代发展潮流、满足现代化、科学化生产生活方式的客观需求。只 有当城市园林景观如同海绵一般更加自如地储积或释放自然降水, 通过规 划设计使原本无规律的降水得以为人驾驭、为民服务, 海绵城市才能更好 地资源全面节约和循环利用。
海绵城市的理念一直都受追捧, 但是用辩证的角度看问题, 不难会有 疑问, 海绵城市的提出是否真的好呢? 真正实施建设是否容易实现呢? 海 绵城市的理念是否对于所有的城市都适用呢? 而答案绝对不是唯一的。如 今, 海绵城市理念的实施, 对干旱的地区效果较为明显, 在雨量较多的城市 的效果并不是很乐观。举个很简单的例子, 在福建福州, 台风暴雨是家常便 饭, 福建的年降雨量大于 $1500 \mathrm{~mm}$, 而在这种地区海绵城市的设计方向并不 适合 “蓄”, “排” 则成了重头戏。对于理念所述的大量使用透水性生态 铺装材料, 即使在道路上都运用了此类型的材料, 也解决不了淹水的问题, 这里不仅除了地面铺装的材质问题, 还要考虑到地下土壤的渗透问题, 土 壤的种类与密度是否会影响排水的速率等。除了土壤, 地下排水设施的设 计与实际施工, 对于现已建好的城市来说, 将道路全部拆除并重新整治的 可能性几乎为零, 而只注重在铺装这种细节来对雨水进行治理, 其作用是 微乎其微的。再者说, 雨水花园的提出, 通过植物沙土综合作用使雨水得到 净化, 并使之渗入土壤, 要求内部系统与外部大环境处于一个相对隔离的 状态, 而这种只适合小领域的单独设计, 在城市大面积的建设中的生态效 益并没有那么高。顾全大局, 由点及面, 把握细节是作为风景园林设计师要 注重的。

\section{4 结束语}

海绵城市建设是生态设计的突破, 是城市发展理念的创新, 是城市建 设方式的转型。将海绵城市理论应用于风景园林规划设计, 可以促进人与 自然的和谐发展, 二者相互作用, 共同构建宜居、节能、生态的城市空间。 在具体实践中, 设计人员不仅要具备海绵城市理论和风景园林规划的知识, 还要结合水土保持等相关理论研究, 重视多者结合的每一个细节, 才能不 断完善海绵城市理论下的城市风景园林建设。

\section{[参考文献]}

[1]刘畅.构建 “海绵城市”一—让城市水资源 “活”起来 [J].国际人 才交流,2016,(04):32

[2]陈硕,王佳琪.海绵城市理论及其在风景园林规划中的应用[J].农业 与技术,2018,(03):128-131。

[3]张蹈.浅析景观生态学——海绵城市理论及其在风景园林规划中 的应用研究[J].农民致富之友,2018,(06):129. 